\title{
The Independence Indicators of the Audit Profession in Spain
}

\author{
Nuria Rodríguez-Ávila ${ }^{1}$, Teresa Monllau-Jaques ${ }^{2}$ \\ ${ }^{1}$ Department of Sociology and Organization Analysis, University of Barcelona, Barcelona, Spain \\ ${ }^{2}$ Department of Economic and Business, University Pompeu Fabra, Barcelona, Spain \\ Email: nrodriguez@ub.edu
}

Received September $19^{\text {th }}$, 2012; revised November $7^{\text {th }}$, 2012; accepted November $19^{\text {th }}, 2012$

\begin{abstract}
The development of professions is framed in the social, political and economic context of our society. Currently, professions are like an essential element of new forms of capital. We consider that the profession of auditor in Spain deserves special attention because the auditor should be adapted to the European Directive 2006/43/CE. The audit profession should be asked: What needs to be the respects of reform so that the profession can be performed as well in the global as in the European context? We studied these aspects of the audit's work: 1) The independence of the audit; 2) The responsibility of auditor has to assume the auditor in the exercise of their profession; 3) What is the women's situation in the profession now in Catalonia? The methodology used for this study was in the first part of the study, we analyzed the independence of the auditor associated to the cost of service by the distribution of the fees and correlated to the Ibex 35 business indicator from 2002 to 2007 in Spain. For the second and third part, we review the literature and the scientific journals to study the auditor responsibility. In conclusion, our study shows some light on the auditor independence in Spain, that it is similar to the other European countries about the quality service review. In the future, we want to analyze the implication of the new legislation for women inside the profession.
\end{abstract}

Keywords: Professions; Auditors; Responsibility; Gender; Quality Control

\section{Introduction}

The 21st century is the century of the Knowledge Society and new professions. This is the century that had changed the world of the communications and the structure of the labor market. It is characterized by the globalization and shows the need of professionals, which have capacities and the adequate skills to be able to adapt to the changes of the labor market (Monllau-Jaques et al., 2009a, 2009b, 2009c). Nowadays, the professions are an essential element in the new forms of social capital. The development of the professions is framed in the social, political, and economic.

\section{The Origin of the Audit's Profession}

The concept of audit is as old as the accounting one. In 1280, Pope Nicolas II revised the accounting by the national notary. In the XV century, Pacioli recognized the importance of verifying that the cash balance was in the debit and the need to verify through inventories the accuracy of the accounting data. During the Renaissance, the Medici introduced in their factories an efficient control on the quantities of raw material used in each one of the phases of production process, and related the quantities supplied in each of the jobs with the units manufactured. It is deduced from these facts that the aim of the auditors was too limiting the risk of frauds and errors.

In the 19th century, the Industrial Revolution caused huge changes in commerce. These changes were related to the increment of the number of workers, the geographical dispersion of the businesses and an incremental, as many in number as in the complexity of the operations that were produced between the business and their environment. Though it is certain that many authors situate the origin of the audit in England, it was in the United States where the profession larger development was produced.

The establishment of the audit in Spain becomes later in time because of the multinationals apparition and by the entrance into the European Economic Community. In fact, the entrance of Spain to the current European Union EU has two consequences that will affect the development of the auditor professsion. First, when the Spanish businesses Internationalization began in the 60 's, with the entrance of Spain to the EU, the number increased as well as the complexity of the transactions among many businesses at a national and international level. Second, it was necessary to adapt the Spanish commercial regulation to the guidelines in force in Europe and to the new needs of the businesses.

The greatest change to the audit profession in our country became in 1988 with the promulgation of the Law of Audit (the Real Decreto 1636/1990 of December 20 by Law 19/1988 of July 12, developed). The most important points were:

1) The definition and delimitation of the audit concept.

2) The establishments of Technical Norms that the auditor should keep in mind in the exercise of the profession, as well as the incompatibilities and the state of applicable infractions to the professionals.

3) The establishment of the representative corporations of auditors.

Nowadays, the own profession demands a reform or a new audit law. Currently, the profession needs to adapt to the new European Directive VIII (Directive 2006/43/CE), the accounting reform has been carried to term in recent years.

The most controversial aspects of the new regulation are:

1) The independence of the auditor.

2) Defining the responsibility of the auditor.

3) Guaranteeing an adequate quality control. 


\section{The Independence}

The independence of the auditor is crucial for the Professional Accounting Associations and the Government. Independence is viewed as "a deeply felt credo of professionalism" (Vanasco et al., 1998). Also, it is a critical component of the profession. The lack of auditor's independence is a main cause of corporate scandals across the world.

Real Decreto 1636/1990 of 20th. December says that "auditors must be independent while performing their duties, of the companies or bodies audited. The Independence is understood as the absence of interest or influences that may be detrimental to the auditor's objectivity. To appreciate lack of independence, among other circumstances, one must consider performance for the company or body audited of other jobs that may limit the auditor's impartiality". The role of the auditor is to give an opinion in reference to the "true and fair view" and in reference to the compliance of the legal requirements and the accounting standards or specific accounting principles. Without auditor's independence, the credibility of financial information will be reduced, and this may be detrimental to the auditing profession itself.

The auditor must be independent. If we would evaluate the independence of the auditor it should be necessary to analyze the difference between:

- Independence in fact (or currently independence): can be defined as the auditor's state of mind, his or her ability to make objective and unbiased audit decisions (Dykxhoorn \& Sinning, 1982; Gul \& Tsui, 1992). It basically refers to the mental attitude of the auditor in terms of professional objectivity.

- Independence in appearance (or perceived independence) refers to the public's or other perceptions of the auditor's independence. This is one of the cornerstones of auditing theory (Buse Von Colbe \& Lutter, 1977; Dykxhoorn \& Sinning, 1981).

The professional proficiency examination aimed a good independence; in fact there are some requisites for registration on the Official Register of Auditors. These are: first to obtain the relevant authorization from the Accounting and Auditing Institute and second to obtain the authorization it is necessary to fulfill and accredit the following conditions (RD, 1990, art 23):

1) Having obtained an official university title.

2) Having completed theoretical training courses.

3) Having acquired practical training.

4) Having passed a professional proficiency examination organized and recognized by the State.

There are some factors influencing auditor independence: amount of audit fees received by the audit firm (in total percentage of audit revenue), non-audit services and the compulsory rotation of audit firms ${ }^{1}$. We are going to study these factors.

\footnotetext{
${ }^{1}$ Empirical studies focused upon identifying the factors which influence independence. Barizah et al. (2005) to refer the following factors:

- The effects of gifts.

- The purchase discount arrangement.

- The audit firm size.

- The provision of management advisory services by the audit firm.

- The client's financial condition.

- The natural conflict issue.

- The audit firm's tenure.

- The degree of competition in the audit services market

- The size of audit fees or relative client size.

The audit committee.
}

\section{Amount of Audit Fees by Audit Firm}

The Cohen Commission (AICPA, 1994) directed attention to the size of audit fees as one of the crucial independence-related issues. The large size of audit fees is associated with a higher risk of losing the auditor's independence. If the size of audit fees is a big proportion of the total audit revenues, it will be a threat to the audit independence. In this situation, it is important to define the criteria in which the proportion is considered dangerous for the independence.

There isn't a definition of the proportion audit fees over total revenues of audit firm in the Spanish Law (Auditoria Law 1988 and The Law of Measures to Reform the Financial System, 2002). The limits are not defined.

The Olivencia Report $(1998 ; 11.2)$ says that the size of audit fees should not exceed 10 percent of total fees. The Law of Measures to Reform the Financial System (2002) and the Aldama Report (2003) considers that in the corporate governance provisions, companies should specify control systems for overseeing the contracts with audit firms for non-audit services and they should be approved by the Audit and Control Commission and disclosed in the annual report.

The VIII Directive (2006; art. 25) says: "State Members shall ensure that adequate rules are used to provide that these fees for statutory audits:

1) Are not influenced or determined by the provision of additional services to the audited entity.

2) Cannot be based on any form of contingency."

In the USA, the Accountants International Study Group (1976) recommended that auditors should be restrained from accepting engagements for which the fees constitute 10 percent or more of the auditors' total fee income. The ICAEW says that the size of audit fees of a major client should not exceed 15 percent of total fees.

\section{Non-Audit Services}

There is an existing debate between Legislators and professionals about the effect of non-audit services in the auditor independence. If the auditor provides non-audit services to the company, there will be two consequences: First, the ratio audit fees over among audit revenues are higher. For the second, these collateral services can create a working relationship between the auditor and the client that is too close. In this situation, the auditor can express a "polluted" opinion about financial statements.

There is unanimity that provides non-audit services to yield higher profit rates than audit fees due. When Levitt speaks about non-audit services, he says: "lucrative consulting contracts”. Some audit fees are too low because auditors have to lower their audit fees to obtain lucrative consulting contracts (SEC 2001). The VIII Directive (2006; art. 25) says: "State Members shall ensure that adequate rules are used to provide that fees for statutory audit: are not influenced or determined by the provision of additional services to the audited entity". For this, it is necessary to have technical rules about audit fees approved by the professional associations. On the other hand, when a company informs about audit fees must differentiate between audit fees and non audit service fees.

Currently, the debate is around non-audit services. Some authors think that providing other services, the auditor's ability to understand client companies is enhanced: it becomes easier to 
make well founded opinions. Legislators say that providing certain non-audit services increase the likelihood of financial reporting that violates generally accepted accounting principles. Some authors say that non-audit services can be negatively associated with restatements because non-audit services increase the information available for the auditor (Goldwasser, 1999; The Panel on Audit Effectiveness, 2002; Dopuch et al., 2003). Other studies found a positive relationship between non-audit services and the auditor's objectivity (Goldwasser, 1999; the Panel of Audit Effectiveness, 2002; Dopuch et al., 2003). Finally, there are studies that have shown that the provision of non-audit services has no effect on auditor independence (Gul, 1989; Coreless \& Parker, 1987).

Analyzing the situation it's necessary to do a classification for the services provided by audit companies. The classification is the following:

- Audit work.

- Financial Information system design and implementation.

- Other services like tax, internal audit services. The conclusions for Kinney (Kinney, 2004) are:

- It is not a statistically significant positive association between fees for financial information system design and implementation or internal audit services and restatements.

- There is a statistically significant positive association between audit fees, audit-related fees, and unspecified nonaudit services fees and restatements.

- Tax service fees are typically negatively associated with restatements.

Legislators think that non-audit services impair auditor independence (Law 19/1988; Directive 2006/43/CE). The SarbanesOxley Act (2002) says that a registered public accounting firm may engage a non-audit service only if the activity is approved in advance by the audit committee of the issuer.

Our opinion is that the audit company can do non-audit service. If it is made a control of quality process and also the clients assume the responsibility, the audit firm can provide these services.

The position of the legislator on this matter is to prohibit the services from audit firms (Law 19/1988 of 12 of July; Managing 2006/43/CE). There are other norms that prohibit the execution of all kinds of works except advice and review on taxes provided that this service has been approved by the committee of audit (Sarbanes-Oxley Act, 2002).

We think that the businesses of audit can carry out different services apart from the emission of a report. This service needs two conditions: Firstly, the financial Law says, the "client assume the responsibility of the global systems of internal control or the service that will be carried out continuing the specifications established by the client, which it should assume the responsibility, execution, evaluation and operation of the system" (Law 44/2002; art. 51e). Secondly, the client is not aware that there is an adequate control of quality on the firms of audit that includes the evaluation of the independence.

\section{The Rotation of the Auditors}

The analysis of the auditor rotation is clear, the all the exercises during the audit of the business are made by the same auditor, links they are created and a relationship among parties implied in the auditors' work a hazard in the independence of the auditor.

Reviewing the regulations, we conclude that it is necessary a rotation to have an efficient auditor's system. This efficiency comes from a double aspect; on one hand, to define a minimum number of years, caused by economies of scale and the knowledge given by the client. On the other hand, also establishes a maximum of years, so difficult situations are avoided which can put in prohibition the independence of the auditor.

We found some divergences in the regulations. On one hand, some regulations talk about contracts with firms of audit (Law of Audit), and about the rotation of the associates (VIII Guidelines). On the other hand, the Law of Audit establishes the duration of audit's contract around 9 years, the VIII Managing talks about an average associates rotation of 7 years.

From our point of view is good to have a regulation which it establishes some limits on the number of years of the duration of the contract of the audit firm and the rotation of the associate responsible for the job.

\section{Empirical Study}

The first objective of the study has been to obtain information on the independence of the audit firms in Spain. The second, the objective has been to analyze the utility of the information facilitated in the annual accounts, in respect to the full fees to the auditors.

The variables analyzed to derive from other studies from Spain (Martinez et al., 2006) and International studies (Barizah et al., 2005; Kinney et al., 2004). The ratio of independence has been analyzed as well as the rotation of the auditors. The ratio of independence has been used to see if the fees received from the auditors put in prohibition its independence. The ratio of independence has been calculated according to the following expression:

$$
\mathrm{RI}=(\mathrm{HC} / \mathrm{I}) \times 100
$$

RI: Ratio of Independence.

FC: Fees received by the auditing firm from the client.

I: Total income of the auditing firm.

To calculate FC we use the information from the annual accounts, which it has been obtained from a consolidated budget. We use this data information for two reasons. First, because it has been possible to verify that in a great number of the businesses analyzed, the same information about the auditors' fees on the annual accounts has been consolidated. In the individual annual accounts is not specified, if the information facilitated is from an individual or from a group of auditors. Second, we worked with the information consolidated, because it is a prudent criteria.

For fee calculation, we have added the fees received in auditor work's concept as the ones received in other work's concept. This way we avoid the effects of the possible transfers of prices among services.

To analyze the auditor rotation, we have evaluated: first, if it has been any changes of the reference period in the auditor firm. Second, if these changes are not regarding the auditors business, we also analyzed rotation of the auditors.

The study sample has been formed by the totality of the businesses in the Ibex 35 index in February, 2009. The period of time analyzed was 2002 until 2007 by CNMV (National Commission on the Securities Market). In 2002 was the first time that the businesses were obliged to report the auditor fees. We eliminated 6 businesses from the Ibex 35 index, because we couldn't find all the information needed. In this period of study 
has been made with 155 observations (Table 1(a)). For the period of time 2008 until 2011 we only have access to the data base SABI (System Iberian Balance Analysis), because we couldn't find all the information needed for all business in CNMV, the approximations were only 46 observations (Table 1(b)).

For the businesses over 15\% RI between 2002-2007, we repeated the calculations they had, but this time bearing in mind the fees received by the auditor according to the individual annual accounts. In nine cases, the calculation has been impossible to carry out, since the data facilitated was insufficient. The results obtained are shown in Table 2.

The analysis of the rotation of the auditors' allows us to conclude that there isn't any problem regarding the rotation of the auditors. We studied the last 6 years, and we observed there has not been any change in the auditor business and the responsibility for the work. Three of the businesses analyzed have changed the associate after 5 years. There are two businesses in which there are two associates that go alternating the firm of the report. The remainder of businesses they change the responsible associates in a period of four years or less. Through the study we have found that women's participation in the signing of the audit reports of large companies is practically nonexistent.

The auditor's professionals in Spain do not have problems of independence. Nevertheless, we consider interesting to remark that:

Table 1.

(a) Ratio of Independence 2002-2007; (b) Ratio of Independence 20082011 (approximation)

(a)

\begin{tabular}{ccc}
\hline & Number of business observations & \% Business \\
\hline RI $<10 \%$ & 130 & $84 \%$ \\
RI $10 \%-15 \%$ & 8 & $5 \%$ \\
RI $>15 \%$ & 17 & $11 \%$ \\
\hline
\end{tabular}

Note: Sources: Monllau and Rodríguez; CNMV (National Commission for the Securities Market) http://www.cnmv.es/portal/home.aspx.

(b)

\begin{tabular}{ccc}
\hline & Number of business observations & $\%$ Business \\
\hline RI $<10 \%$ & 46 & $100 \%$ \\
RI $10 \%-15 \%$ & 0 & $0 \%$ \\
RI $>15 \%$ & 0 & $0 \%$ \\
\hline
\end{tabular}

Note: Source: SABI (System Iberian Balance Analysis).

Table 2.

Calculate the independence ratio from the information of the individual annual accounts 2002-2007.

\begin{tabular}{ccc}
\hline & Number of business & \% Business \\
\hline RI $<10 \%$ & 7 & $42 \%$ \\
RI $10 \%-15 \%$ & 0 & $0 \%$ \\
RI $>15 \%$ & 1 & $6 \%$ \\
& 9 & $52 \%$ \\
\hline
\end{tabular}

Note: Source: Monllau and Rodríguez.
1) The study has limitations since only allow us to conclude on the big business audits. Any business of the Ibex 35 has been audited as a small or medium business.

2) The information on the annual accounts, was not specified in a high percentage of the accounts analyzed.

3) The information given is individual or consolidated.

4) There are a few businesses that indicate the percentage that the fees of audit suppose to the total of the billing of the auditor Firm.

5) The data of previous years are shown on a few businesses.

6) All the businesses received different services apart from those of auditing.

\section{The Role of the Auditor Women in Spain}

The role of auditor Spanish women has been changed over the time. We have to emphasize the role played by Carrera et al. (2001) in which the situation and development of women in the auditor profession are studied. The conclusion reached by the authors of the study is that within the period under review, representation of women as a percentage of all new members goes from $0 \%$ during the period $1942-1945$ to $13.67 \%$ during the period 1984-1988. Other authors like Garcia et al. (2009) provide information on the percentage woman represent in the four largest auditing firms in our country. In the companies where this percentage is higher the percentage of women members is less than 20\%. As shown in Tables 3 and $\mathbf{4}$ (actual professional volume and number of women today).

So the conclusion we are driven into is that the influence of women in the auditor profession is not relevant. We'll have to wait for a period of time for the adoption of the new rules, to analyze whether there has been a significant change in this sense.

\section{Conclusion}

Spain is promulgating a new Law of Auditoria. This situation is very interesting to create a debate about the more polemic aspects in the Auditing Profession. The purpose of this article is to focus in auditor's independence, auditors' responsibility and quality results.

Our conclusions must be interpreted with caution because across our sample it is only possible to study and conclude about the tendencies of The Big Audit Firms. On the other hand, the study is important because we have a first approximation to the audit firm's behavior in Spain.

The study shows some light on the auditor independence. We find that the audit firms that work in Spain have an acceptable independence but, sometimes, the information in the annual reports is very confusing and the data base to find the information are not the systematic.

The ratio of independence RI > 15\% between 2002-2007 it is low, but we could find any observations with RI $>15 \%$ for the period 2008-2011.

There is still no consensus about the role of the external auditor and its responsibility. Our conclusion is important to make us think about the balance between the auditor's responsibility and business's needs.

The situation in Spain is similar to the other countries regarding the quality service review. A good quality review system is important, because without it, more probably competency violations can occur. The audit profession in Spain is 
Table 3.

Auditor profession map in Catalonia, 2010.

\begin{tabular}{ccccccccc}
\hline & \multicolumn{2}{c}{ Barcelona } & \multicolumn{2}{c}{ Tarragona } & \multicolumn{2}{c}{ Lleida } & \multicolumn{2}{c}{ Girona } \\
\cline { 2 - 8 } & $\mathrm{N}^{\circ}$ & $\%$ & $\mathrm{~N}^{\circ}$ & $\%$ & $\mathrm{~N}^{\circ}$ & $\%$ & $\mathrm{~N}^{\circ}$ & $\%$ \\
\hline Society & 287 & 8.27 & 34 & 16.83 & 29 & 17.26 & 33 & 14.16 \\
Men & 2513 & 72.40 & 139 & 68.81 & 112 & 66.67 & 157 & 67.38 \\
Women & 671 & 19.33 & 29 & 14.35 & 27 & 16.07 & 43 & 18.45 \\
Total & 3471 & 100 & 202 & 100 & 168 & 100 & 233 & 100 \\
\hline
\end{tabular}

Note: Source: Monllau and Rodríguez.

Table 4.

Women in auditor profession in Catalonia, 2010.

\begin{tabular}{ccccccccc}
\hline & \multicolumn{2}{c}{ Barcelona } & \multicolumn{2}{c}{ Tarragona } & \multicolumn{2}{c}{ Lleida } & \multicolumn{2}{c}{ Girona } \\
\cline { 2 - 9 } & $\mathrm{N}^{\circ}$ & $\%$ & $\mathrm{~N}^{\circ}$ & $\%$ & $\mathrm{~N}^{\circ}$ & $\%$ & $\mathrm{~N}^{\circ}$ & $\%$ \\
\hline Individual & 58 & 8.64 & 7 & 24.13 & 7 & 25.93 & 4 & 9.30 \\
By contractor & 84 & 12.52 & 3 & 10.34 & 2 & 7.41 & 7 & 16.28 \\
Exercise partner & 67 & 9.99 & 3 & 10.34 & 4 & 14.81 & 2 & 4.65 \\
No exercise & 462 & 68.85 & 16 & 55.17 & 14 & 51.85 & 30 & 69.77 \\
Total & 671 & 100 & 29 & 100 & 27 & 100 & 43 & 100 \\
\hline
\end{tabular}

Note: Source: Present authors.

healthy but it is necessary to think and study about the most controversial aspects.

\section{REFERENCES}

Accountants International Study Group (1976). Independence of Auditors Study. New York.

http://openlibrary.org/books/OL23747363M/Independence_of_audit ors

American Institute of Certified Public Accountants (AICPA) (1978). Commission on auditors' responsibilities: Report, conclusions, and recommendations. New York: Cohen Commission.

American Institute of Certified Public Accountants (AICPA) (1994). Committee of Sponsoring Organizations of the Treadway Commission [COSO], Internal Control-Integrated Framework Jersey City, NJ.

Barizah, N., Rahim, A. I., \& Majdi, H. (2005). Factors influencing auditor independence: Malaysian loan officers' perceptions. Managerial Auditing Journal, 2, 804-822.

Buse Von C. W. I., \& Lutter, M. (1977). Auditing today: Development or reform? Paper presentat al Ein Bochumer Symposium.

Carrera, N., Gutiérrez, I. Y., \& Carmona, S. (2001). Gender, the state and the audit. Profession: Evidence from Spain. The European Accounting Review, 10, 803-815.

Coreless, J. C. I., \& Parker, L. M. (1987). The impact of MAS on auditor independence: An experiment. Accounting Horizon, 20, 707-718.

Directive 2006/43/EC of the European Parliament and of the Council of 17 May 2006 on statutory audits of annual accounts and consolidated accounts, amending Council Directives 78/660/EEC and 83/349/ EEC and repealing Council Directive 84/253/EEC.

http://eur-lex.europa.eu/LexUriServ/LexUriServ.do?uri=CONSLEG: 2006L0043:20080321:EN:HTML

Dopuch, N., King, R. I. \& Schwartz, R. (2002). Independence in apperance and fact: An experimental investigation. Contemporary Accounting Research, 20, 79-114. doi:10.1506/9B5D-HLLP-BBQE-8N3F

Dykxhoorn, H. J. I., \& Sinning, K. E. (1981). Wirtschaftsprufer percep- tion of auditor independence. The Accounting Review, LVI, 97-107.

Dykxhoorn, H. J. I., \& Sinning, K. E. (1982). Perceptions of auditor independence: Its perceived effect on loan and investment decisions of German financial statement users. Accounting, Organizations and Society, 7, 337-3347. doi:10.1016/0361-3682(82)90009-5

Goldwasser, D. L. (1999). The task awaiting the ISB. Accounting Today, 7, 52-54.

Gul, F. A. (1989). Bankers' perceptions of factors affecting auditor independence. Accounting, Auditing and Accountability Journal, 2, 4051. doi:10.1108/09513578910132303

Gul, F. A. I., \& Tsui, J. S. L. (1992). An empirical analysis of Hong Kong bankers' perceptions of auditor ability to resist management pressure in an audit conflict situation. Journal of International Accounting, Auditing and Taxation, 1, 177-190. doi:10.1016/1061-9518(92)90015-8

Kinney, W., Palmrose, Z. Y., \& Scholz, S. (2004). Auditor independence, non-audit services, and restatements: Was the US government right? Journal of Accounting Research, 42, 561-588. doi:10.1111/j.1475-679X.2004.t01-1-00141.x

Law 44/2002 Measures to reform the financial system B.O.E. num 69 de 8 de November.

Monllau, J. T., \& Rodríguez, Á. N. (2009a). The new legislative framework of the audit profession. Partida Doble. Revista de Contabilidad. Núm. Especial Diciembre Directorio Financiero Partida Doble, 10-15.

Monllau, J. T., \& Rodríguez, Á. N. (2009b). Changes in the audit profession? Partida Doble. Revista de Contabilidad. Auditoria y Empresa, 12-13.

Monllau, J. T., \& Rodríguez, Á. N. (2009c). The challenges of the audit profession in Spain. Partida Doble. Revista de Contabilidad. Núm. 213. Septiembre. Auditoria y Empresa, 28-39.

Martínez, L., Rodríguez, A., \& Yubero, P. (2006). Auditor independence and conflicts of interest in auditing. Partida Doble, 180, 54-67.

Olivencia Report (1998). El Gobierno de las Sociedades Cotizadas, Comité especial para el estudio de un código ético de los consejos de administración de las sociedades Madrid.

Real Decreto 1636/1990 de 20 de diciembre por el que se aprueba el Reglamento que desarrolla la Ley 19/1988, de 12 de julio de 


\section{N. RODRÍGUEZ-ÁVILA, T. MONLLAU-JAQUES}

Auditoría de Cuentas. B.O.E. núm. 308, de 25 de diciembre.

Rodríguez, Á. N., \& Monllau, J. T. (2010). El nou paradigma docent i la problemàtica de la implatanció davant bolonya en les escoles d'empresarials. Els estudis en empresa cobreixen les expectatives dels empresaris? Revista de Sociología (UAB), 95, 213-226.

Securities and Exchange Comisión (SEC) (2001). Office of the Chief
Accountant. Independence Rule Proxy Disclosures, Independent Accountant Fees: Fortune 1000 Companies Data List on 563 Proxy Filings as of April 30, 2002.

Vanasco, R. R. (1998). Frau auditing. Managerial Auditing Journal, 13, 4-71. doi:10.1108/02686909810198724 